\title{
Faszination Radiologie - die Patienteninformationen der DRG
}

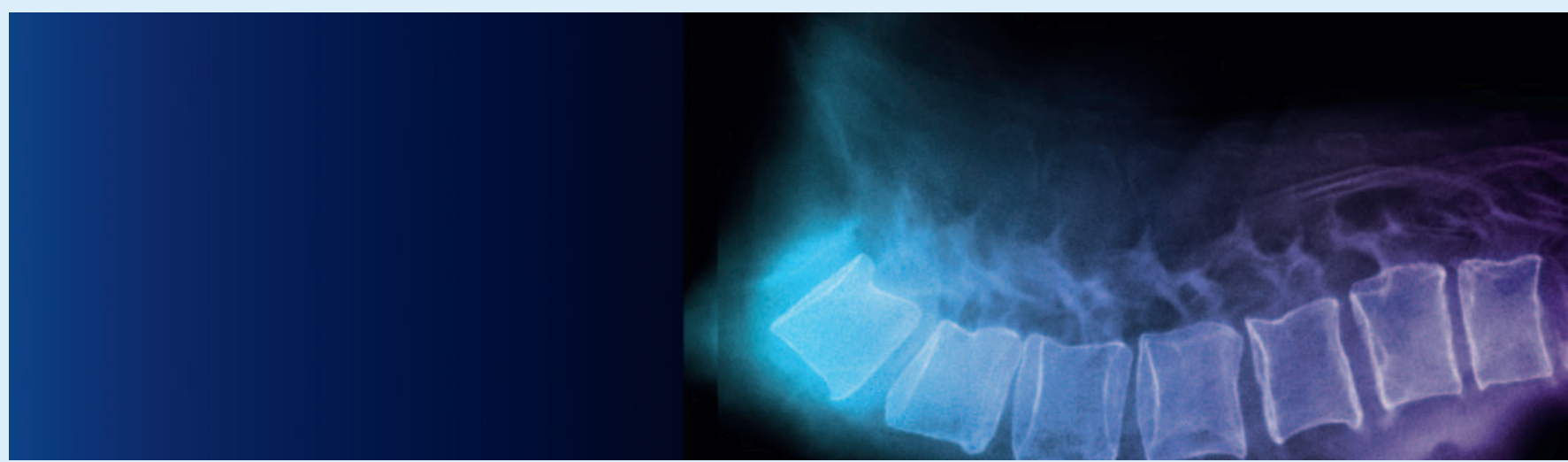

Kennen Sie schon die Patienteninformationen der DRG? Auf www.drg.de haben wir viel Wissenswertes rund um die Radiologie aufbereitet und beantworten Fragen wie: Was macht eine Radiologin? Wie funktioniert ein CT? Wo arbeitet ein MTRA? Auf der Webseite der DRG können Patientinnen und Patienten die faszinierende Welt der Radiologie entdecken. Sie erhalten außerdem praktische Servicetipps, beispielsweise zur Vorbereitung auf die nächste Röntgenuntersuchung oder wie man der Angst vor der MRT-Untersuchung begegnet.
Erzählen Sie Ihnen Patientinnen und Patienten also gerne von unserem Webangebot. Laufend stellen wir hier weitere Informationen zu Verfahren und Einsatzfeldern bereit.

Mehr erfahren Sie unter drg.de > Patienteninfos 